\title{
Eläinterveys hiehonkasvatuksen ulkoistamisessa
}

\author{
Olli Ruoho ${ }^{1)}$, Vesa Rainio ${ }^{2)}$, Kati Partanen ${ }^{3)}$, Tapani Kivinen ${ }^{4)}$, Veli-Matti Tuure ${ }^{5)}$ \\ 1) Eläintautien torjuntayhdistys ETT Ry, etunimi.sukunimi@ett.fi \\ 2) Elintarviketurvallisuusvirasto EVIRA, etunimi.sukunimi@gmail.com \\ 3)Savonia-ammattikorkeakoulu, PL 72, 74101 Iisalmi, etunimi.sukunimi@savonia.fi \\ 4) MTT Kotieläintuotannon tutkimus, Vakolantie 55, 03400 Vihti, etunimi.sukunimi@mtt.fi \\ 5)TTS-Työtehoseura, PL 5 Kiljavantie 6,05201Rajamäki, etunimi.sukunimi@tts.fi
}

\section{Tiivistelmä}

Hiehonkasvatuksen ulkoistaneen tilan keskeisimpiä huolenaiheita on eläinten terveys. Tautiriskin lisäksi keskeisiä terveysnäkökohtia ovat tapaturmariski sekä hiehon valmius poikimiseen ja sen jälkeisiin aineenvaihdunnan muutoksiin.

Uusien tarttuvien eläintautien määrä riippuu ensisijaisesti karjakontaktien määrästä. Siis siitä, kuinka monelta tilalta eläimiä tulee tai on tullut. Myös muut tilojen väliset kontaktit, kuten yhteiskuljetukset, yhteislaidunnus, yhteiset työvälineet ja koneet sekä tilojen välinen henkilöliikenne vaikuttavat. Tautiriskiin vaikuttavat myös tilojen tautitilanne ja suojauskäytännöt. Yleensä tilan tautitilannetta ei täysin tunneta, ja siksi yksi kontaktitila lisää tarkoittaa aina tautiriskin lisääntymistä.

Hiehojen siirto muualle kasvatettavaksi toisaalta pienentää, toisaalta kasvattaa tartuntojen riskiä. Riskiä pienentää se, että nuorkarja on tartuntoja ajatellen karjan vaarallisin osa. Lehmät ovat jo kohdanneet tilalla olevat taudinaiheuttajat ja muodostaneet niille vastustuskyvyn. Nuorkarjassa on kuitenkin yksilöitä, jotka ovat jo saaneet tartunnan, mutta eivät vielä parantuneet ja levittävät tartuntaa edelleen vasikoihin. vasikoiden terveydelle voi olla eduksi, että nuorkarja siirretään pois esimerkiksi 3 - 4 kuukauden iässä.

Tilapari tai tilarengas on turvallinen. Jos kasvattamossa on vain yhden lypsykarjatilan eläimiä, on se tarttuvien tautien kannalta lähes riskitön. Jos kasvattamoon ei tule muualta eläimiä ja se noudattaa samantasoista hygieniaa ja rehuturvallisuutta kuin lypsykarjatila, hiehot eivät saa tartuntoja sen helpommin kuin kotitilallakaan. Jos kasvattamoon tulee eläimiä useammalta tilalta tautiriskiä voi pienentää, jos mikään tiloista ei osta eläimiä muualta. Tilarenkaan tautitilanne on huonompi tai yhtä hyvä kuin renkaan huonoimman tilan. Tilarengas on suojatumpi kuin yksittäinen tila, joka ostaa vuosittain hiehon tai lehmän milloin mistäkin. Tilarenkaassa vaaditaan kuitenkin kaikkien sitoutumista, eikä eläimen osto omaan karjaan ole enää yksityisasia.

Salmonella pysäyttää kasvattamon eläinliikenteen ja tartunnan saneeraaminen omalla kustannuksella tulee kalliiksi. Hiehokasvattamot eivät saa salmonellavakuutusta meijereiden ja teurastamojen kautta ryhmävakuutuksena, mutta tilakohtaisen vakuutuksen ottaminen on suositeltavaa.

Hiehokasvattamon käyttöasteen tulisi olla korkea, jotta investoinneista saa kannattavan. Jos lähettäjätiloilta ei tule riittävästi eläimiä, tekisi mieli ostaa muualta. Tautitorjunnan kannalta tämä on huono vaihtoehto. Ulkopuolisten eläinten tulo hiehokasvattamoon on erityisesti lypsykarjatilojen etu. Siksi on hyvä sopia, että lypsykarjatila maksaa hiehokasvattamon eläinpaikoista varausmaksua. Kasvattamo saa siten korvauksen kaikista eläinpaikoista ja on lypsykarjatilan oma asia, miten suurta osaa varaamistaan paikoista se käyttää.

Hiehonkasvatuksen ulkoistamisella tulee pyrkiä siihen, että hiehojen hoito paranee kotioloihin verrattuna. Ruokinnan osalta tähän on hyvät edellytykset. Hiehoja ruokitaan nimenomaan hiehojen ehdoilla ja kasvattamo voi tuottaa ja käyttää täyttävämpää säilörehua kuin lypsykarjassa on mielekästä.

Asiasanat: hiehot, ulkoistaminen, hoito, eläintaudit, hygienia 


\section{Johdanto}

Tautiriskin lisäksi hiehonkasvatuksen keskeisiä terveysnäkökohtia ovat tapaturmariski sekä hiehon valmius poikimiseen ja sen jälkeisiin aineenvaihdunnan muutoksiin.

Tautiriskin kannalta paras vaihtoehto on yhtä tilaa palveleva hiehonkasvattamo, jonne ei tule eläimiä muilta tiloilta. Toiseksi paras on ulospäin suljetun tilarenkaan kasvattamo, jonne tulee eläimiä vain muutamalta nimetyltä tilalta, jotka eivät hanki eläviä eläimiä muualta kuin kyseisestä kasvattamosta ja toisiltaan.

\section{Tauti voi tulla mistä vain}

Uusien tarttuvien eläintautien määrä riippuu ensisijaisesti karjakontaktien määrästä. Siis siitä, kuinka monelta tilalta eläimiä tulee tai on tullut. Myös muut tilojen väliset kontaktit, kuten yhteiskuljetukset, yhteislaidunnus, yhteiset työvälineet ja koneet sekä tilojen välinen henkilöliikenne vaikuttavat.

Tautiriskiin vaikuttavat myös tilojen tautitilanne sekä tautisuojauskäytännöt. Yleensä tilan tautilannetta ei täysin tunneta, ja siksi yksi kontaktitila lisää tarkoittaa aina tautiriskin lisääntymistä.

Joitain tauteja voi siirtää muukin eläin kuin nauta. Lammas ja vuohi ovat monen nautataudin mahdollisia kantajia, myös jyrsijät ja linnut ovat merkittävä tartuntojen lähde. Ihmisestä nautoihin ja päinvastoin tarttuvat sairaudet ansaitsevat erityistä huomiota, koska ne muodostavat elintarvike- ja työturvallisuusriskin. Ulkomailla hyönteiset ja hämähäkkieläimet ovat usein hankalia taudinlevittäjiä.

Rehu tai vesi ovat tartuntalähteitä lähinnä ulosteperäisten bakteeritartuntojen, kuten salmonellan ja EHEC:n kohdalla. Rehualan riskinhallinta on Suomessa varsin hyvä, eikä teollisten rehujen välityksellä levinneitä salmonellatartuntoja ole todettu nautatiloilla viime vuosikymmenellä. Vuosittain kuitenkin todetaan muutama tartunta. Yleisin tartuntalähde on lintujen ja jyrsijöiden ulosteillaan saastuttama väkirehuvarasto, rehunkäsittely- tai ruokintalaitteisto tai juomavesi.

Virusperäiset hengitystietulehdus- ja ripulitartunnat sekä myös itiöiden mukana leviävä pälvisilsa voivat levitä ilmateitse lyhyehköjä matkoja. Hengitystietulehdukset siirtyvät sopivissa sääolosuhteissa jopa tilalta toiselle.

\section{Nuorkarja on riski vasikoille}

Hiehojen siirto muualle kasvatettaviksi toisaalta pienentää, toisaalta kasvattaa tartuntojen riskiä.

Riskiä pienentää se, että nuorkarja on vasikoiden tartuntoja ajatellen karjan vaarallisin osa. Lehmät ovat jo kohdanneet tilalla olevat taudinaiheuttajat ja muodostaneet niille vastustuskyvyn. Nuorkarjassa on kuitenkin yksilöitä, jotka ovat jo saaneet tartunnan, mutta eivät vielä parantuneet - ja levittävät tartuntaa edelleen vasikoihin. Vasikoiden terveydelle voi siten olla eduksi, että nuorkarja siirretään pois esimerkiksi 3 - 4 kuukauden iässä.

Jos hiehonkasvatuksen voi ulkoistaa siten, ettei kosketusta ulkopuolisiin karjoihin synny, voivat tartuntasairaudet jopa vähentyä.

\section{Tilapari tai tilarengas on turvallinen}

Jos kasvattamossa on vain yhden lypsykarjatilan eläimiä, on se tarttuvien tautien kannalta lähes riskitön. Jos kasvattamoon ei tule muualta eläimiä ja se noudattaa samantasoista hygieniaa ja rehuturvallisuutta kuin lypsykarjatila, hiehot eivät saa tartuntoja sen helpommin kuin kotitilallakaan. Mutta jos lypsykarjatila ostaa eläimiä muista karjoista, se ottaa aina riskin uuden tartunnan tulosta karjaan.

Kun hiehonkasvattamosta haluaa pääelinkeinon, yhden tilan eläinten kasvattaminen voi olla kannattamatonta. Kasvattamon on siis palveltava useaa tilaa. Tautiriskiä voi silloin pienentää kasvattamalla vain tiettyjen tilojen eläimiä. Tilanne on tautien suhteen hallittu, jos mikään tiloista ei hanki eläimiä muualta. Eläinten kuljetukset tulee hoitaa puhtaalla kalustolla siten, että samoissa kuljetuksissa ei ole muita eläimiä.

Tilarenkaan tautitilanne on huonompi tai yhtä hyvä kuin renkaan huonoimman tilan. Useimmat taudinaiheuttajat kulkeutuvat joka tilalta hiehonkasvattamoon ja sieltä edelleen renkaan muille lypsykarjatiloille. Alkuvaiheessa on odotettavissa lisää sairastelua (hengitystietulehduksia, ripuleita, tartunnallisia sorkkasairauksia) sekä kasvattamossa että lypsykarjatiloilla. Sittemmin tilanne tasaantuu, kun uusille mikrobikannoille syntyy renkaan kaikissa karjoissa vastustuskyky. 
Tilarengas on suojatumpi kuin yksittäinen tila, joka ostaa vuosittain hiehon tai lehmän milloin mistäkin. Renkaassa vaaditaan kuitenkin kaikkien sitoutumista, eikä eläimen osto omaan karjaan ole enää yksityisasia, joka tehdään omalla riskillä.

\section{Tyhjät paikat minimiin varausmaksulla}

Hiehonkasvattamon käyttöasteen tulisi olla korkea, jotta investoinnista saa kannattavan. Jos lähettäjätiloilta ei tule riittävästi eläimiä, tekisi mieli ostaa vasikoita muualta. Tautitorjunnan kannalta tämä on huono vaihtoehto.

Parempi olisi sopia, että lypsykarjatilat toimittavat enemmän vasikoita kuin tarvitsevat uudistukseensa. Apua voi olla esimerkiksi sukupuolilajitellun sperman käytöstä. Lypsykarjatila ja kasvattamo voivat sopia keskenään, kumman lukuun ylimääräiset vasikat kasvatetaan. Ylimääräisten eläinten myynti ulkopuolisille ei vaaranna hiehonkasvattamon tautiturvallisuutta, jos ostajat käyttävät suojavaatteita eikä eläinten kuormauksen yhteydessä tuoda vierasta lantaa rehu- ja eläintiloihin.

Ulkopuolisten eläinten tulon estäminen hiehonkasvattamoon on erityisesti lypsykarjatilojen etu. Siksi on hyvä sopia, että lypsykarjatila maksaa hiehonkasvattamon eläinpaikoista varausmaksua. Kasvattamo saa siten korvauksen kaikista eläinpaikoista ja on lypsykarjatilan oma asia, miten suurta osaa varaamistaan paikoista se käyttää. Varausmaksun tulisi kattaa paitsi eläinpaikkaan kohdistuva rakennuskustannuksen kuoletus, myös korvaus siitä, että eläimelle on varattu rehua ja hoitotyötä.

\section{Paljon ostovasikoita, paljon tauteja}

Jos hiehonkasvattamo ostaa vasikoita lähes mistä vain, kasvattamossa voi pian olla melkein kaikki Suomessa esiintyvät nautojen taudit. Kansainvälisesti ajatellen tilanne on silti melko hyvä, koska maassamme ei juuri ole vakavimpia karjasairauksia.

Etenkin hengitystietulehduksia on kuitenkin odotettavissa, samaan tapaan kuin lihanautakasvatuksessa. Pälvisilsaa on Suomessa ehkä prosentilla lypsykarjatiloista, joten jos vasikoita on ostettu pariltasadalta tilalta, kasvattamossa on todennäköisesti tämä sitkeä sieni-ihottuma. Suolistossa viihtyviä taudinaiheuttajia, joista osa on ihmisellekin vaarallisia, kertyy sekä teorian että kokemuksen mukaan tiloille, jotka ostavat vasikoita kymmeniltä tai sadoilta tiloilta.

\section{Säännöllinen terveydenhuolto on osa tautiriskien hallintaa}

Sekä hiehonkasvattamon että maitotilojen kannattaa kuulua Nautatilojen terveydenhuollon seurantajärjestelmä Nasevaan, jolloin eläinlääkäri käy säännöllisesti terveydenhuoltokäynneillä ja tilojen tautitilanne dokumentoidaan. Nasevasta on mahdollista tulostaa "Tilan tautitilanne"- raportti, josta näkyvät terveydenhuoltokäynnin havainnot, käynnin ajankohta ja tilalle vuoden aikana ulkopuolelta tulleet eläimet.

Tavoitteena on, että tilat täyttävät Nasevan kansallisen tason vaatimukset eli ovat vapaita salmonella-, BVD- ja pälvisilsatartunnoista. Näistä pälvisilsa on hiehonkasvattamon toimintaa ajatellen hankalimmin hallittavissa oleva tautiriski, koska se saattaa esiintyä piilevänä ja puhjeta vasta kasvattamossa. Pälvisilsa on pitkällinen saneerattava, ja ainakin periaatteessa se pysäyttää kasvattamosta ulospäin suuntautuvan eläinliikenteen puoleksi vuodeksi.

Lypsykarjatilojen salmonellavakuutuksen ehdot edellyttävät tilalle siirrettäviltä eläimiltä alle kahden kuukauden ikäistä negatiivista salmonellatutkimustulosta. Sama vaatimus sisältyy eläinten hyvinvoinnin tuen ehtoihin.

Hiehonkasvattamoihin suuntautuvan liikenteen kohdalla tutkimusvaatimus riippuu kasvattamon vakuutusehdoista, mikäli sille on otettu salmonellavakuutus. Hiehonkasvattamot eivät saa vakuutusta meijereiden tai teurastamoiden kautta ryhmävakuutuksena, mutta tilakohtaisen vakuutuksen ottaminen on suositeltavaa. Salmonella on viranomaisten toimesta vastustettava tauti ja tilalla todettu tartunta tuo mukanaan rajoittavat määräykset. Kasvattamon eläinliikenne pysäytetään, kunnes tila on saneerattu tartunnasta vapaaksi. Salmonellan saneeraaminen tilalta omalla kustannuksella tulee kalliiksi.

Tarttuvan virusripulin eli BVD:n osalta riittää, että huolehtii mahdollisten tuontialkioiden vastaanottajien tutkimisesta ETT:n ohjeiden mukaisesti; ohjeet tähän löytyvät ETT:n kotisivuilta; www.ett.fi. Suomi on todettu käytännössä vapaaksi BVD- tartunnoista, eikä tauti siten leviä eläinsiirtojen mukana. 


\section{Tautiriskiä voidaan avoimessakin toimintamallissa hallita}

Vaikka suljettu tuotantorengas on tautiriskien hallinnan kannalta paras vaihtoehto, voidaan tautivaaraa avoimessakin toimintamallissa pienentää rajoittamalla tilamäärää ja selvittämällä

vasikoiden lähtötilojen tautitilanne esimerkiksi Nasevan kautta.

Mitä vähemmän on tiloja, joilta hiehonkasvattamo ostaa vasikoita, sitä harvemmalta tilalta on mahdollista saada tauteja kasvattamoon. Mikäli vasikat ostetaan aina samoilta lähtötiloilta, voidaan päästä hyvinkin vakaaseen tautitilanteeseen. Tautiriskiä pienentää myös, mikäli lähtötilat eivät osta eläimiä muilta tiloilta tai ostavat niitä vain kyseisestä hiehonkasvattamosta.

Hiehonkasvattamoon menevät vasikat on kuljetettava niin, että ne eivät saa matkalla lisää tartuntoja. Vasikoita ei kuljeteta osana välitysvasikka- tai teuraskuormaa. Kuljetusajoneuvon tulee olla pesty ja desinfioitu edellisen eläinkuljetuksen jälkeen.

Vasikoiden lähtötilojen tautitilannetta voidaan varmistaa ostamalla vasikoita vain tiloilta, jotka kuuluvat Nasevaan. Näille tiloille tehdään vuosittain terveydenhuoltokäynti, jolla käydään läpi tilan tautisuojaustoimenpiteet sekä tilanne salmonellatutkimusten, pälvisilsan sekä muidenkin tarttuvien tautien suhteen. Käytännössä on oleellisinta huolehtia siitä, että kasvattamoon ei vasikoiden mukana saada salmonella- tai pälvisilsatartuntoja.

Ihanteellisinta on, jos vasikat voidaan ostaa tilalta, jonka tautitilanne on vakiintunut sekä tutkittu, ja jolle ei lähikuukausina ole tullut eläimiä muilta tiloilta. Lisävarmuutta asiaan saadaan edellyttämällä vasikoiden lähtötilalta ETT:n kotisivuilta (www.ett.fi) kohdasta "Ohjeet ja lomakkeet/eläinkauppa/lomakkeet" löytyvä Nautakarjan terveystodistus, joka on voimassa kaksi kuukautta allekirjoituspäivästä, mikäli tilalle ei tänä aikana ole ostettu eläimiä.

\section{Muitakin terveysuhkia on}

Navetan rakenteet ovat keskeisiä tapaturmavaaran kannalta. Pahimmillaan eläimet voivat kaatua ja loukkaantua ylösnousukyvyttömiksi liukkaalla pihaton käytävällä. Aitojen ja porttien yli hyppivät kiimaiset eläimet jäävät toisinaan kiinni mahastaan tai raajastaan vakavinkin seurauksin. Betonipalkkiritilöiden välit voivat olla murenemisen tai palkkien liikkumisen vuoksi juuri sen verran leveitä, että jalka tai sorkkapuolisko juuttuu kiinni ja vaurioituu.

Hiehonkasvatuksen ulkoistamisella tulee pyrkiä siihen, että hiehojen hoito paranee kotioloihin verrattuna. Ruokinnan osalta tähän on hyvät edellytykset, koska hiehonkasvattamo voi tuottaa ja käyttää täyttävämpää säilörehua kuin lypsykarjassa on mielekästä.

Jotta hieho poikii terveenä, se on ruokittava ja tiineytettävä asianmukaisesti. Tavoitteena on, että hiehon lantio on poikiessa laaja ja häpyliitos luutunut normaalisti - näin kummastakaan ei muodostu synnytysestettä. Näihin vaaditaan riittävä energiansaanti sekä tasapainoinen kivennäis-

ruokinta D-vitamiineineen.

Hieho tulisi siirtää takaisin lypsykarjatilalle tottumaan bakteerikantaan ja hoitokäytäntöihin noin kaksi kuukautta ennen poikimista. Hiehoa on tässä vaiheessa helpompaa ja terveellisempää lihottaa kuin laihduttaa. Siksi kasvattamolla on vastuu siitä, ettei hieho ole liian lihava.

Lihavana poikiva hieho altistuu helpommin aineenvaihduntahäiriöille. Se menettää ruokahaluaan ja samalla vastustuskykyään. Poi'ittuaan se lypsää huonommin, saa herkemmin utaretulehduksia, kohtutulehduksia ja juoksutusmahavikoja sekä tiinehtyy huonosti.

\section{Yhteenveto}

Hiehonkasvatukseen liittyvä tarttuvien eläintautien riski on parhaiten hallinnassa suljetussa toimintamallissa, jossa hiehonkasvattamoon tulee eläimiä vain yhdeltä tai muutamalta nimetyltä tilalta, joille ei osteta eläimiä renkaan ulkopuolella. Avoimessa toimintamallissa voidaan tautiriskejä hallita rajoittamalla lähtötilojen määrää ja selvittämällä niiden tautitilanne ennen vasikoiden ostoa ja siirtoa hiehonkasvattamoon.

Hiehonkasvattamon käyttö voi myös parantaa tilan eläinten terveydentilaa, mikäli se onnistutaan toteuttamaan lisäämättä tilojen välisiä kontakteja. Tässä tilanteessa tarttuvat eläintaudit saattavat jopa vähentyä, sillä tilan sisäiset tartunnat nuorkarjasta vasikoihin vähenevät. Hyvässä hiehon-kasvattamossa hiehojen ruokinta saadaan yleensä täsmällisemmin niiden tarpeita vastaavaksi kuin kotitilalla - tällä on suuri merkitys hiehon ensimmäisen poikimisen ja ensimmäisten tuotoskuukausien onnistumiselle. 


\section{Itsestään selviä tautisuoja-asioita?}

Hiehonkasvattamossa ei pidetä muita kotieläimiä, kuten lampaita, vuohia tai siipikarjaa.

Lampailla ja vuohilla esiintyy kinokuumetta, joka voi tarttua nautoihin. Siipikarjaan liittyy salmonellariski. Suositeltavaa on, että samassa tilassa kasvatushiehojen kanssa ei pidetä myöskään muita nautoja.

Kasvattamoon ei tulla muilla kotieläintiloilla käytetyissä varusteissa.

Jalkineisiin ja vaatteisiin tarttuu lantaa, eritteitä ja pölyä, joiden mukana voivat levitä muun muassa salmonella ja EHEC, virusperäiset hengitystietulehdukset ja ripulit sekä pälvisilsa.

Tuontirehut ja -rehuaineet hankitaan ETT:n positiivilistan toimittajalta.

Jos tuo rehua maahan itse, se tutkitutetaan salmonellan varalta Eviran ohjeiden mukaan.

Haittaeläinten ja lintujen torjunnasta eläinsuojassa ja etenkin rehuvarastoissa huolehditaan.

Yleisin salmonellatartunnan lähde nautatiloilla on lintujen ja jyrsijöiden saastuttama rehuvarasto, rehunkäsittely- tai ruokintalaitteisto tai laitumella myös juomavesi.

Kuivitus ja lannankäsittely toteutetaan niin, että rehun ja lannan kuljetusreitit eivät risteä ja eläimet pysyvät puhtaina.

Hyvä ruokinta- ja rehuhygienia ennaltaehkäisee ulosteperäisten bakteeritartuntojen leviämistä.

Ulkomailta ei tuoda tauteja sairaiden ihmisten, vaatteiden eikä tuliaisruokien välityksellä.

Mikäli ulkomailla on vieraillut kotieläintilalla, ei kotimaassa saa mennä eläintiloihin, ennen kuin tilakäynnistä on kulunut 48 tuntia. Ulkomailla käytetyt vaatteet ja jalkineet pestään ja desinfioidaan.

Ulkomailta ei tuoda liha- tai maitotuotteita. Mikäli matkan aikana sairastuu kuumeeseen tai ripuliin, on kotimaahan palattua syytä teettää salmonellatutkimus ennen menoa kotieläintiloihin. Matkoilla tulee noudattaa hyvää käsihygieniaa.

Käsittelytilat kuntoon!

Hiehonkasvattamoon tulee ja sieltä lähtee eläimiä useita kertoja vuodessa. Rakenteiden ja kulku- reittien tulee olla sellaisia, että siirrot voi tehdä sekä ihmisten että eläinten kannalta turvallisesti.

Kasvattamossa tulee olla myös mahdollisuus eläinten kytkemiseen hoitotoimenpiteitä, siemennystä tai tiineystarkastusta varten. Sairaiden ja loukkaantuneiden eristämistä varten tarvitaan riittävästi kytkentämahdollisuudella varustettua sairaskarsinatilaa. 